\title{
ICT-BASED INSTRUCTIONAL MATERIAL DEVELOPMENT: A STUDY OF COMMUNICATION DEPARTMENT STUDENTS
}

\author{
M. Teguh Prasetiyo \\ Email: teguh.prastmuhammad@gmail.com
}

Graduate Program of English Language and Literature Education, State University of Surabaya

Surabaya, Indonesia

\begin{abstract}
Technology as an essential matter has been integrated in today's education for the sake of innovative and cutting-edge medium for English language teaching (ELT). Also, the students' demands in learning English should be accommodated since they are in relation to the specialized study or the professional required of the students. This paper attempted to explain how the process of ICT-based instructional materials for undergraduate students of Communication Department is developed. This reseach occupies Richards (2001) model of R and D. There were three groups participated to this research. The students $(N$ $50)$, lecturer $\left(\begin{array}{ll}N & 1\end{array}\right)$ and the curriculum coordinator $(N 1)$, from those three participants were achieved by triangulation with respect to data collection sources. The finding shows that most of the respondents agree to use ICT-based instructional material in their learning process. It means ICT-based instructional material is proper to be implemented since the practicality and ease of usage. The feedback from the students indicates that they like the appearance of the instructional material and it attracts the students to use it to support their learning.
\end{abstract}

Keywords: Information, Communication and Technology, Need Analysis.

\section{INTRODUCTION}

In recent years, we can't close the eyes to that interactive multimedia which dominates the field of language teaching. An effective teaching can be done easily by using the ICT - interactive multimedia in learning and teaching process. It will provide the professional real world demand than those traditional textbooks. However, we can't decline the popularity of textbook despite common 
enthusiasm for numerous modern tools. Not everyone is interested in using ICT-based instructional materials. Hutchinson and Torres (1994, p. 314) argue that a textbook is still the most important teaching aid since it does not only survive but also it thrives. It can be said that textbooks clearly survive because they satisfy certain needs. It is considaring that not every area covered by the technology and internet sotextbook is still the most commonly used in the teaching and learning process. On the other hand, one of Tomlinson (2008, p. 3) arguments is that many ELT (English Language Teaching) materials especially global course books currently make a significant contribution to the failure of many learners of English as a second, foreign or other languages to even acquire basic competence in English and to the failure of most of them to develop the ability to use it successfully. They do so by focusing on the teaching of linguistic items rather than on the provision of opportunities for acquisition and development.

In this case, Schoology was used in this research finally to help the students and lecturers in learning process. Nicolas Borg and Jeff O'Hara developed Schoology in 2008. It is a learning management system (LMS) for the higher education institution. This web application allows the users to create, to manage, and to share content and resources. It is also known as a course management system (CMS) or Virtual Learning Environment (VLE), the cloud-based platform provides tools to manage any classroom or blended learning environment. At the moment, it is very rare finding the specific tailormade syllabus, materials designed specifically in this field and ICT based instructional material development. This thesis will focus on a needs analysis which aims to identify what students are requiring the foreign language for; which in turn helps to specify as closely as possible what exactly students have to learn in that language in the form of ICT and how it helps of the process ICT based instructional material development.

\section{METHODS}

This research and development used educational Research and Development as the design in this study to find out a specific style in the ESP instructional materials. The prime objective of this research is 
to develop ICT - based ESP instructional materials which is appropriate with the students' needs of communication department in the University of Pembangunan Nasional East Java (UPN). The participants are the students of Communication Department (N 50), English and Basic Journalism lecturer $(N \quad 1)$ and the curriculum coordinator $\left(\begin{array}{l}N \\ 1)\end{array}\right)$; The ESP instructional materials are intentionally developed based on the language program for a compulsory course which the students have to take in the semester.

In this study, the data obtained were analyzed by using descriptive qualitative method. The $1^{\text {st }}$ and the $2^{\text {nd }}$ data gathered from interview and questionnaire in need analysis and situation analysis were rated and described to find out the percentage of the data. The data was interpreted descriptively to show the needs of the lecturers, learners and the institution of the English program and to show how well the situation support and expatiation of the program. The identified need, then, was used as the basis for the next developmental stages to develop goal, objectives and syllabus, for the process of developing the material with the contextual teaching and learning based approach. After developing and drafting the material, the product including content and application was validated. The $3^{\text {rd }}$ data taken from the expert validation checklistwas analyzed to validate the product before being implemented. It is to identify which items needed to be revised, and which item needed to be removed based on the suggestion of the expert. The indicators which are used to validate the product are with rating criteria totally lacking, very poor, adequate, good and excellent while the materials which inappropriate or ineffective was rated poor or totally lacking. The criteria arebased on Guideline for evaluating indicator by Miekley (2005). During the implementation phase, the $4^{\text {th }}$ and the $5^{\text {th }}$ data were taken. Questionnaire was given to the students, and the data obtained was rated and analyzed to obtain the data on how well the material fit the program and to find out the critique, comment or input to revise the material. The $6^{\text {th }}$ data came from peer appraisal and learners' appraisal survey and questionnaire. The purpose of this data was to know the response and opinion on the developed material and to find 
out any critique, comment or input to accomplish the process in finishing the final product.

\section{RESULTS \& DISCUSSION \\ The Process of Developing ICT-Based Instructional Material for Communication Department Students}

In sufficient detail of the process of development, Richards (2001) R and D model is used in conducting the research. It covered the need analysis, the design phase, the material development, the validation and the evaluation.

\section{Need Analysis and Situation Analysis}

The process of developing instructional material is started from need analysis to know the students', lecturer and institution need in learning the target language. Richards (2001, p. 52) states that need analysis are used for a number of different purposes such as to find out what language skills needed, to determine if an existing course is adequately address the needs of the students, to collect information about students' problem and what the students' need to be able to do.

In reference to Richards' theory of need analysis, the desired data were obtained. Firstly, the questionnaire shows that the majority of the students (88\%) have good perspective in learning English that can help the lecturers to teach more easily in the learning process. However, since most of them (66\%) face difficulty in learning English, the lecturers are challenged to encourage the students to be more interested in it. Specifically, the most difficult skill to enhance is listening (40\%), followed by speaking (30\%), writing (20\%) and the least difficult skill for them is reading (5\%). In addition, the most difficult English component is understanding grammar (20\%). The common reason for that difficulty is caused by the skills and the components which are not taught communicatively; they were merely taught through its rules or formula without the real-world tasking instead. Lightbown and Spada (1999, pp. 91-92) agree that learning in natural context just like on the street is more affective rather than learning the second language focusing on the so called traditional instructional environment (grammar translation). The data from the instrument lead the English lecturer to find out the appropriate way 
for teaching English in that department. This information can adjust the essential material based on the students' difficulty in learning English.

The participants attended English 1 course of "General English" in the first semester as the requirement to continue to take English 2 course of "English for specific purpose" in the second semester. The students' score in the final test of English 1 course elaborated with the data from questionnaire show that most of them are excel in reading $(67 \%)$ and writing (52\%).

Figure 1. Students' score in the final test of English 1 course

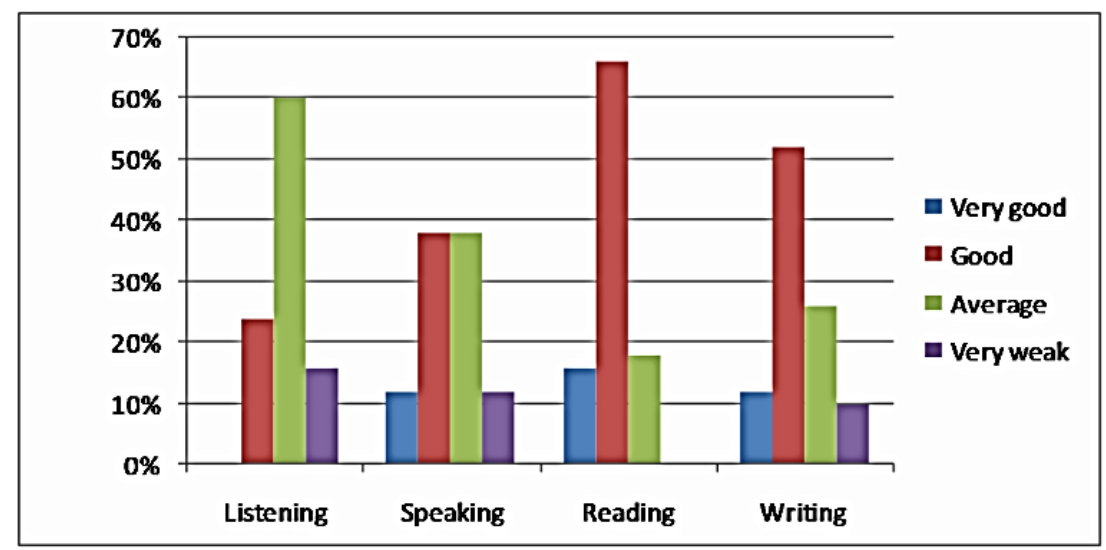

Further, Basturkmen (2006, p. 16) states that students are taught in the form of another variety of English instead of general English, after they learned general English as the basic English, they are to study the ESP as the next English adjusted through their field of study. The students will be successful in acquiring the language with the proper motivation. Based on the result of the questionnaire, the majority of the students have high motivation in learning English (64 \%). Zoltan Dornyei (1998, p. 117) states that motivation has been widely accepted by both teachers and researchers as one of the key factors that influence the rate and success of second/foreign language (L2) learning. Despite the difficulties of learning English faced by the students, they still have eagerness in learning English. However, the lecturers should stimulate the students in order to keep their motivation through the interesting media and to correlate the English 
learning which is appropriate for their needs and wants in learning English.

The learning model is a design study that will be conducted by teacher in the classroom. The successful of the teaching and learning process is influenced by the way the lecturers deliver the material to the students. Based on the students' experience in learning English, the situation of the class is boredom, monotone with the over students capacity. As a result, the lecturer cannot give a balance attention proportion to each student. In addition, the students cannot focus constantly to the learning process. Nasreen and Naz (2013 cited in Andrini, 2016) mention one of the factors affecting low learning outcomes is learning model. Use a less precise model of learning in the learning process may lead a boredom or burnout, lack of understanding of concepts, and monotonous so that students are less motivated to learn.

The problems mentioned above lead the students to have innovative learning process. Most of students agree to use blended learning activity (54\%) and ICT-based instructional material (62\%) since they cannot focus constantly to the learning process as an impact of over students' capacity in a class. From the result finding the students have been generally technology literate which helps to relate the curriculum outside the classroom then, add the dimension of the foreign language learning, particular with the use of technology. Paltridge and Starfield (2013, p. 385) declare that technology has long played a major role in the teaching of English for specific purpose (ESP) in two distinct ways, first as a tool to assist the traditional types of language learning and the second is to create a space new forms of communicating. ICT-based instructional material is expected to improve effectiveness and efficiency in order to gain the main teaching and help lectures to adapt to ESP teaching model and high teaching load.

In order to help them to enhance more in English competencies, the students are required not only to learn English in the class but also outside of the class. Watterston (2012, p. 5) mentions that blended learning is ranged from the very broad where practically any learning experience that integrate some use of ICTs 
qualities, to others that focus on specific percentage of online curriculum and face to face instruction. It can assist to achieve the objectives of the learning process since the students and lecturer not only keeps in touch in the class but also outside of the class by using the internet.

However, besides supported by using the internet in the learning process, they also want to have opportunity to practice their English through role playing activity in the classroom. It can be said that having a good opportunity to practice English in front of the class through role playing will help them to improve their English speaking skill. In doing the assignment, the students want to do it either individually or in group in role playing as well as having discussion section in the learning process. The purpose of discussion is to get another view from each student.

From the result of the need analyses, it can be concluded that the participant want to have a good ability in all aspects of English language skills (listening, speaking, reading and writing) and their components (grammar, pronunciation, vocabularies). The students in communication department are expected to be able to write the news and to conduct interviewas a part of journalism field. In writing news and conducting interview in English of course, the specific vocabularies to support their performance in the journalistic field are required. It takes the consideration from the developer to add all integrated skills and English components in ESP instructional material for English 2.

\section{Design Phase}

The following step is design phase using Richard's R and D model. They are planning goal, objectives and syllabus design. A syllabus describes the major elements that will be used in planning a language course and provides the basis for its instructional focus and contain (Richards, 2001, p. 152). Lecturer especially those who are teaching English for specific purpose are strived for designing the instructional material for students. It is in line with Belcher (cited in Paltridge \& Starfield, 2013, p. 6) who states that ESP specialist accept the responsibility to find out what their learners' will likely need (and want) to be able to read, write, speak and comprehend as listeners to 
achieve their goal. It is important since the students demand specific needs in mastering English.

\section{Syllabus design}

Considering the data collected from need analysis, the proposed syllabus was developed based on the existing basic journalism syllabus. The target of this program is for adult learners who are majoring in communication department. That is why; the instructional materials should reflect what they need in their specific field of study. Based on the existing syllabus of basic journalism, the developer designs content based syllabus to integrate and to organize the ESP language teaching and learning process within the content of basic journalism. Topical or content based syllabus is organized by themes, topics, or the unit of content (Richards, 2001, p. 157). It can be said that the instructional materials are integrated to second or foreign language teaching while the target language as the vehicle rather than the immediate object of study. Brinton (as cited in Richards, 2001, p. 158) claims the advantage of content based syllabus are to facilitate comprehension, to make the linguistic form more meaningful, to serve content as the best basis for teaching the skill area, to address the students' need, to integrate of the four skills and to allow for use the authentic materials. In this phase, the proposed syllabus and the prototype of the instructional materials were completed.

In accord to the present syllabus observation, the course materials only focus on the reading skill and grammatical structure, it cannot help the students in developing their mastery of English. Hence, the proposed materials are developed in such a way that are consist of the instructional materials and the task that enable the students to develop the skills they need to master English. The proposed material is in the form of integrated materials including listening, speaking, reading and writing accompanied by relevant grammar structure, vocabularies, videos in context and relevant task.

\section{Preparing and Selecting the Material}

The next step is the process of instructional material transformation into the web application platform. The design of 
interactive application follows the format of learning management system of Schoology. The developer chooses Schoology since it is the combination between social media and online learning management system. One of the strengths of the internet for ESP teaching is the availability of different types of both oral and written text. DudleyEvans and St John (1998 cited in Paltridge \& Starfield, 2013, p. 391) suggest that the ESP lecturers find copies of syllabi and other authentic course materials such as newspaper, magazine, scientific journal, audio, video and lectures need only turn on their computers.

From the aforementioned discussion of both the present syllabus and the proposed syllabus many differences were clearly noticeable. Firstly, the present syllabus does not set the basic competence which decides each skill should be mastered by the learners. Consequently, the indicators are not constructed properly. Furthermore, the objectives of the syllabus are not suitable to the ESP principle since it focus only to reading and structure. The materials were constructed randomly without specific themes and units and they were given to the students even haphazardly. Moreover, the materials were taken only from one reference. The teaching method used is not described specifically in the syllabus and the assessment is not mentioned.

Meanwhile, in the proposed syllabus, the basic competence is formulated based on the basic journalism syllabus. The indicators were developed specifically based on the Bloom's Taxonomy level and the ESP principles. For instance, the students are able to demonstrate the functional expression through role playing. As for the materials and the exercises, they were constructed to eight unit materials following the current issues which might be upgraded any time.

From those eight topics, it is expected to be able to fulfill what the students' need to learn English for specific purpose (journalism field). All integrated skills are provided in the instructional materials including grammar structure and vocabularies in context. All of those topics and skills based on the emphasis the students gave as shown from the data collected from them in need analysis. In order to encourage the students to learn, the developer attempted to create the task and 
material based on their department and integrated to internet with Schoology web application.

The instructional materials mentioned above are integrated to ICT with Schoology. The result of the development in this step is the product of Schoology which contains of eight topics of English Basic Journalism for communication department in the second semester.

\section{Validation of the product}

The next step in instructional material development is product validation phase. Three aspects were evaluated such as cultural visual images, cultural information, and discussion of cultural practices about journalistic. In the part of exercises and activities it is suggested that they should engage the students to apply grammar in communicative way as stated byRichard and Rodgers (1986, pp. 16-17)that approaches and methods in language teaching can be derived from theoretical view of language and the nature of language proficiency underlying them. It can be the method of the lecturer in transferring the knowledge to the students. The lecture should give the task to the students with sociolinguistic strategies and communicative task. This theory emphasized the semantic and communicative dimension more than grammatical characteristic of language. In other words, the learners are not only expected to implement the structure of grammar but also expected to implement the structure of grammar in communicative dimension. It will bring benefits for students to participate the language based on their needs in specific purpose.

The initial intensive consultation to the ICT expert resulted significant judgment of the web application. The first criterion of the ICT validation is the access to the content of web application. Shank (2007, p. 217) says that the access to the learning content in web applicationmust be easily accessible so that all members of the target audience can quickly find the information they need. The result of ICT expert validation showed that the access to the web application is easy since it is well known application used by million education professional in nearly every corner of the world. The web application is standard multimedia format software application. The content is easily accessed to students in online and interactive community. The 
users of web application are able to download easily through some devices such as mobile phone, tablet and computer. Moreover, the users can download it freely without spending money but internet connection fee. From this validation, the web application is properly used by the students and lecturers in supporting the learning process. For the aspect of flexibility, the result of validation shows that the application is flexible and the students can use it simply without other software to support in using the application since it does not need extra software or plug in.

The next criterion is the design of web application. It is important since the students are the target user of the application. The students will likely to get less attracted to read and follow the activities in the materials when the web application is boring and complicated. Martí (2006, p. 121) claims that the design of web page should be well structured; the individual pages should be concise and short enough to avoid having to scroll. In addition, a web site should be easy to navigate and working hyperlinks. The interface of the design web application is out of question to improve. Students' attention ought to be caught through the first impression when they firstly look at the design before they read more.

For the aspect of navigation, the users of web application have already been familiar to operate Facebook as a result they are supposed to be able to navigate easily. The elements of Schoology are also ease of use, visual appeal and technology support. When the users access the web application for the first time they will not get difficulty since the visual appealing is easily noted. The graphics and clearly soft tone colors might be caught easily by the students on the main page. The interface of Schoology does not appear much information such as advertisement that makes visual elements distraction but it is easily accessible. From the aspect of function of features in Schoology, itis one of the ultimate web applications which can manage, engage students, content sharing and connect with the lecturers. The developer almost uses all the features to manage the virtual class in creating assignment, quiz, hosting discussion, grading and working hyperlink that can connect with other sources from the internet. It can give wider information and knowledge for the students. All of them 
can be done as simple as posting to the social media. In conclusion all of the features are functioned should have been they are to help the learning process. As a result, expert claimed that Schoology is interesting and helpful application to assist in learning process.

Generally, for overall validation of the web application, the expert says that Schoology is appropriate to support the learning process for its practicality and ease of implementing Schoology. It can cover all aspects in creating and sharing resource such as instructional material, adding images, audio, video, assignment, quiz, grading and discussion in one central. Clark and Mayer (2008, p. 57) state that based on cognitive theory and research evidence, it is recommended to include words and video, rather then words alone in E-learning process. By words, we mean printed text (that is, words presented as speech that people listen to through earphones or speakers).Multimedia presentations can encourage learners to engage in learning activityby mentally representing the materials in words and in pictures. In contrast, presenting words alone may encourage learners especially those with less experience to engage in shallow learning, such as not connecting the words with other knowledge. In other words, Schoology is appropriate web application in supporting the learning process in this technology era.

\section{Evaluation phase}

The product was evaluated through formative and summative evaluation in the classroom using blended learning. In informative evaluation, there was four product try-out sessions. The first try-out showed that the students need more guidance to operate the web application as it was their first time. The students also were still reluctant to give their answer because of lack of vocabularies. The betterments were added by giving more discussion of using vocabularies in context, showing the guidance through projector to ease the demonstration of using Schoology and adding the example video about the certain topic.

Summative evaluation during the learning process was conducted to the learners. In this phase, the students are required to be self-learners. They learn for intermediate level and to acquire personal 
meaning. They were asked to work in group and give peer feedback, and they see the instructor as coach or helper. The learners prefer methods that allow them to interact with peers and obtain coaching from the instructor. Based on the constructivism theory, Cooper (1993 cited in Anderson \& Elloumi, 2004) informs that recently, there has been a move to constructivism. Constructivist's theory claims that learners interpret information and the world according to their personal reality, and that, they learn by observation, process and interpretation, and then personalize the information into personal knowledge. From the activities in the learning process, the developer as the facilitator and collaborator as English lecturer found the students were doing the activities enthusiastically since it is the first experience for students in blended learning. The students' feedback indicates that they like the appearance of the instructional material. The Facebook model of the design attracts the students to use it to support their learning.

In part of the topic, the students agree that the instructional material provide journalism topic since it was developed based on the syllabus of basic journalism as well as the need analysis. The students also have opportunity to have discussion with friends and lecturers about the topics of journalism in other countries via online. Paltridge and Starfield (2013, p. 385) say that technology has been used in variety of ESP classes to create contexts for communicating with oral, literate, and visual mode of discourse such as chatting, where the participants interact in the same time frame, or synchronous form such as the features provided in the Schoology. In implementing the materials, the students have opportunity to use the target language in both oral and written in English such as in short writing essay, making dialogue and discussion.

The problem in this phase of implementation was the students have difficulty to understand the instruction of the unit. It means the students want to have clearer instruction provided in instructional material. To make the instructional material better, the developer upload the instructional material with the clearer instruction. The students also still depended on the lecturer to get new knowledge of the topic. They do not use the internet connection maximally to assist 
them in understanding the lesson. To make the students familiar with the internet connection, the developer added source link about additional material in the internet. Another problem occurred during the implementation of the materials was in the default setting of the listening quiz. The problem was the ten questions that were set to the one slot of question. As a result the students will not get any point or zero point of doing the quiz till they can do all questions correctly. To solve the problem, it has been set correctly for ten listening questions for 10 slots. It means that the correct answer decide the point which the students get in doing the listening test by the total score is 100 points.

\section{The Final Product}

The chart above shows the statistical result of students' evaluation of instructional material. Ten choices were clearly answered by students to explain their opinions about the instructional material. Most of students gave "good" score for the design of the instructional material both content and the application. The feedback from the students indicated that they like the appearance of the instructional material. The Facebook model of the design attracts the student to use it to support their learning.

Figure 2. Result of students' instructional material evaluation

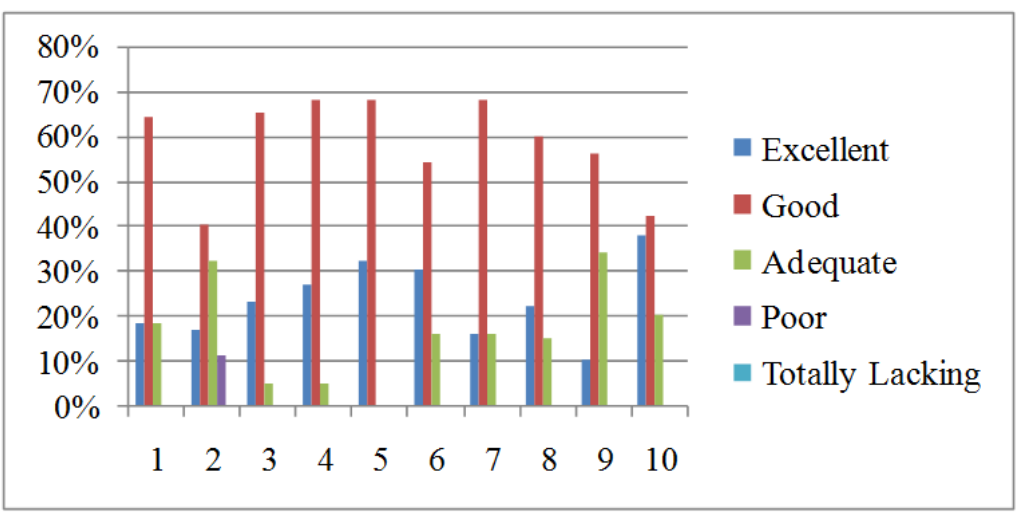

Visual imagery took the second phase to be discussed. As many as $40 \%$ of participants gave "good" score for the visual imagery, however, $32 \%$ of the participant need it to be revised. Most of the 
students are interested in reading the text since as many as $65 \%$ of the participant gave a "good" score. When they were asked about the sequence of the topic, the participants said that sequenced topically from the simple topic to the complex one.

By the total of $68 \%$ of the participant agree that the topic is about journalism while a few of them did not agree with them. Most of the students agree that the instructional material provide journalism since in developing the material based on the syllabus of basic journalism as well as the need analysis. There are some discussions about journalism in other countries such as in unit one talking about journalism in America and Indonesia while in listening skill in unit three is discussing about press freedom in some countries such as in America and Egypt. The existing of those materials, 54\% chose "good" while $30 \%$ of the participant chose "excellent". Those indicated that they can learn the journalism topic from other countries while the rest by the total of $16 \%$ chose "adequate". In implementation of the instructional material, there were variety of activities in learning process such as short writing essay, discussion and speaking dialogue etc. Those activities provided the students use the target language in both oral and written. That is why the participants by the total of $68 \%$ chose "good". It means they could use the target language in communicative way.

By the total $60 \%$ of the participants stated that by using the application, they could learn both academic and functional expression in English. Based on the students' needs in need analysis, the students want to be able to use English in daily life. From that result, the developer developed the instructional material containing functional expression in each unit related to each topic. Afterward, instruction is one of the crucial aspects in instructional material. Despite of $56 \%$ of the participants gave "good" score for the instruction unfortunately as many as $34 \%$ of the participants gave "adequate". It means the students want to have clearer instruction provided in instructional material.

The last discussion is the language level of instructional material. "Poor and totally lacking" were not chosen by the participants, it means no revision needed in this phase. While good was chosen by $42 \%$ of the participants and $38 \%$ of participants gave "excellent" while only $20 \%$ of participants said "adequate". It showed that the level of language 
materials was not too easy and not too difficult which means it is suited them.

\section{Result of expert test item and media validation}

A good media should meet the set criteria. Therefore, two phases of test item and media validation were carried out. The product must be rated with Excellence and good criteria to be considered as a good and proper product. The first draft of ESP instructional material content was judged adequate in some aspect such as grammar and vocabularies which are not suit the grammar focus with the topic and to add the additional vocabularies such as glossaries and difficult word in each reading text. The revisions were carried at that time to improve the quality of the product. The second draft passed the criteria written in the validation with the perfect point. The expert gave a point Good for almost criteria meaning no need revision while Poor and totally lacking as the indicator of needed revision were not chosen. Meaning the instructional materials are ready to be implemented to the participants.

The initial intensive consultation to the ITC expert resulted significant judgment of the web application. Generally, for overall validation of the web application is totally good for both aspects "access and design" meaning no need revision. However, the expert gave a useful suggestion to make ICT better used in the learning process. The suggestions were given by the expert in previous phase of the development becomes precious thing for the developer to attain the material improvement. All of the weaknesses and revision based on the suggestion from the expert in the previous material development were revised to be a better product name the final prototype.

\section{CONCLUSIONS}

The result of findings and discussion showed that the instructional material in English for specific purpose does not relevant with the specific field of the students' department. The provided instructional material is adopted merely general English with the emphasis of reading and grammar based teaching. The goal of the curriculum as well as the students is to be able to create a discourse, 
oral and written especially in specific purpose. The lecturer taught merely English structure in English 2 course rather than using it in the real context of languagee. Furthermore, the learning process is merely in traditional class which relies on textbook, whiteboard and the presence of both students and lecturer in the class. Besides, the department has provided a complete facility to support innovative learning with Schoology web application. In this research, ICT-based instructional material was successfully developed through $\mathrm{R}$ and $\mathrm{D}$ model which covered some steps based on (Richard, 2001, p.41). Those are; need analysis and situational analysis, planning goal and learning outcome, course planning and syllabus design, preparing and selecting materials, and providing effective teaching and implementing the product and followed by evaluating it. As a result, the final product can meet the students' demand in learning English. The final product of ICT-based instructional material has been validated by the experts. In accord to the curriculum with the integration to the students' need requiring specific field of the department in learning English. Based on the experts' judgment, ICT-based instructional material is proper to be implemented in the learning English for specific purpose for communication department since the practicality and ease of usage.

Starting with the discussion of the potential of online technologies for language learning, this thesis suggests it is important to maximize the potential for intention to wider learning context as a media to motivate the use of technology. The learners should be facilitated by the department to use the internet for English language learning based on their demand. For the lecturer, the existing web application-based instructional material can be an alternative medium in the learning process besides traditional lecturing in the classroom. The lecturer can upload the material and give assignment to the learners through the web application. Then, the learners can access the material by themselves every time, everywhere and evaluating themselves to measure their understanding of the material with doing the online assignment provided in the web application. Suggestion for the next researcher, ICT-based instructional material development can be developed wider covering other interesting materials. The ICT based instructional material as one of resources can be developed to 
other educational institutions where has not been optimized the use of the internet technology in the learning process. Hopefully, the existing of the web application can be new innovation in educational sector in order the learning process can be either flexible or limited by the time and place.

\section{REFERENCES}

Anderson, T., \& Elloumi, F. (Eds.). (2004). Theory and Practice of Online Learning. Canada: Athabasca University.

Andrini, V. S. (2016). The Effectiveness of Inquiry Learning Method to Enhance Students' Learning Outcome: A Theoritical and Empirical Review Education and Practice, 7(3).

Basturkmen, H. (2006). Ideas and Options in English for Specific Purposes. New Jersey: Lawrence Erlbaum Associates, Inc.

Clark, R. C., \& Mayer, R. E. (2008). E-Learning and the Science of Instruction (2 ed.). San Francisco: Pfeiffer.

Dornyei, Z. (1998). Motivation in second and foreign language learning. Language Teaching, 31(03), 117-135.

Hicks, W. (2007). English for Journalist (3 ed.). New York Routledge.

Hutchinson, T., \& Torres, E. (1994). The textbook as agent of change English Language Teaching, 48, 316-328.

Hutchinson, T., \& Waters, A. (1987). English for specific purpose a learning-centered approach. Cambridge: Cambridge University Press.

Inan, F. A., \& Lowther, D. L. (2010). Factors affecting technology integration in K-12 classrooms. A path model Education Tech Research Development, 58(2), 137-154.

Lightbown, P., \& Spada, N. (1999). How Languages are Learned (Second ed.). Oxford: Oxford University Press.

Martí, M. D. M. C. (2006). Teacher Training In ICT-Based Learning Settings: Design And Implementation of An On-Line Instructional Model For English Language Teachers UNIVERSITAT ROVIRA I VIRGILI.

Nandika, D., Priowirjanto, G. H., \& Soekartawi. (2007). Integrating ICT For Better Quality and Values of Education: Lesson from 
Indonesia. Paper presented at the 42nd Seameo Council Conference, Nusa Dua, Bali, Indonesia.

Paltridge, B., \& Starfield, S. (Eds.). (2013). The handbook of English for specific purposes. United Kingdom: Wiley-Blackwell.

Richard, J. C., \& Rodgers, T. S. (1986). Approaches and methods in Language Teaching. Cambridge: Cambridge University Press.

Richards, J. C. (2001). Curriculum development in language teaching. Cambridge: Cambridge University Press.

Shank, P. (Ed.). (2007). The Online Learning Idea Book. San Francisco: Pfeiffer.

Tomlinson, B. (Ed.). (2008). English Language Learning Materials A Critical Review. London: Continuum Internationa.

Watterston, D. J. (2012). Blended learning. State of Victoria (Department of Education and Early Childhood Development). Ultranet and Digital Learning Branch Department of Education and Early Childhood Development Melbourne 